\title{
Моксифлоксацин як альтернатива в лікуванні хворих на вперше діагностований туберкульоз легень у разі монорезистентності до піразинаміду чи його непереносимості
}

Кужко М.М. ${ }^{1}$, Бутов Д.О. ${ }^{2}$, Гуменюк М.І. ${ }^{1}$, Процик Л.М. ${ }^{1}$, Гречаник Л.І. ${ }^{3}$, Тараненко А.В. ${ }^{1}$

1. ДУ «Національний інститут фтизіатрії і пульмонології ім. Ф.Г. Яновського НАМН України», м. Київ, Україна

2. Харківський національний медичний університет, м. Харків, Україна

3. Національний військово-медичний клінічний центр «Головний військовий клінічний госпіталь», м. Київ, Україна

Мета. Визначення ефективності застосування моксифлоксацину замість піразинаміду в інтенсивну фазу хіміотерапії у хворих на вперше діагностований туберкульоз легень у разі монорезистентності до останнього чи його непереносимості.

Матеріали та методи. У наше дослідження було включено 64 хворих на деструктивний уперше діагностований туберкульоз легень із бактеріовиділенням. Хворі були розподілені на дві групи: 1-ша - 34 хворих, які замість піразинаміду отримували перорально моксифлоксацин упродовж інтенсивної фази лікування (2 місяці); 2-га 30 хворих, які отримували стандартне лікування. Групи були зіставні між собою за віком, статтю, профілем резистентності тощо.
Результати. Через 4 тижні лікування припинення бактеріовиділення, визначене методом мікроскопії, спостерігалося у 23 хворих (67,6 \%) 1-ї групи та в 16 (53,3 \%) 2-ї групи (p>0,05). Через 8 тижнів припинення бактеріовиділення мікроскопічно спостерігалося в 31 пацієнта (91,2 \%) 1-ї групи й у 24 (80 \%) - 2-ї групи (р>0,05). Закриття деструкцій після завершення інтенсивної фази лікування відзначалося у 12 хворих (35,2 \%) 1-ї групи та в 9 (30 \%) 2-ї групи (р>0,05).

Висновки. Заміна піразинаміду на моксифлоксацин не призводить до зниження ефективності лікування порівняно зі стандартною хіміотерапією, тому може бути альтернативою в лікуванні при монорезистентності до піразинаміду чи його непереносимості. 